Access policy and money market segmentation

Sébastien Kraenzlin and Thomas Nellen

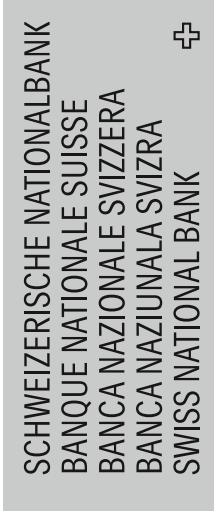


The views expressed in this paper are those of the author(s) and do not necessarily represent those of the Swiss National Bank. Working Papers describe research in progress. Their aim is to elicit comments and to further debate.

\section{Copyright $\odot$}

The Swiss National Bank (SNB) respects all third-party rights, in particular rights relating to works protected by copyright (information or data, wordings and depictions, to the extent that these are of an individual character). SNB publications containing a reference to a copyright ( $\odot$ Swiss National Bank/SNB, Zurich/year, or similar) may, under copyright law, only be used (reproduced, used via the internet, etc.) for non-commercial purposes and provided that the source is mentioned. Their use for commercial purposes is only permitted with the prior express consent of the SNB.

General information and data published without reference to a copyright may be used without mentioning the source.

To the extent that the information and data clearly derive from outside sources, the users of such information and data are obliged to respect any existing copyrights and to obtain the right of use from the relevant outside source themselves.

\section{Limitation of liability}

The SNB accepts no responsibility for any information it provides. Under no circumstances will it accept any liability for losses or damage which may result from the use of such information. This limitation of liability applies, in particular, to the topicality, accuracy, validity and availability of the information.

ISSN 1660-7716 (printed version)

ISSN 1660-7724 (online version)

๑ 2012 by Swiss National Bank, Börsenstrasse 15, P.0. Box, CH-8022 Zurich 


\title{
Access policy and money market segmentation
}

\author{
Sébastien Kraenzlin and Thomas Nellen*
}

July 26, 2012

\begin{abstract}
We analyse deviations between interest rates paid in the Swiss franc unsecured money market and the respective Libor rate. First, banks that have access to the secured interbank market and the SNB's monetary policy operations pay less than banks without access. Second, domestically unchartered, foreign banks pay more than domestic banks. We find that these segmentations are limited both during normal times and during the financial crisis starting 2007 thanks to open access to the secured interbank market and the SNB's monetary policy operations. These findings reveal that a neglected aspect of monetary policy implementation matters, namely access policy.
\end{abstract}

JEL-Codes: E58, G21, G28

Keywords: access to central bank money, unsecured interbank money market, money market integration and segmentation, financial crisis

\footnotetext{
* Sébastien Kraenzlin, Head Money Market, Money Market and Foreign Exchange, Swiss National Bank (E-mail: sebastien.kraenzlin@snb.ch). Thomas Nellen, Economic Advisor, Financial Stability - Oversight, Swiss National Bank (E-mail: thomas.nellen@snb.ch). The authors are indebted to Jean-Pierre Danthine, Basil Guggenheim, Juerg Maegerle, Cyril Monnet, Felix Schafroth, Andy Sturm and Benedikt von Scarpatetti for valuable discussions. The authors also thank the anonymous referees for valuable comments and suggestions. The views expressed in this paper are those of the authors and do not necessarily represent those of the Swiss National Bank.
} 


\section{Introduction}

The financial crisis starting 2007 revealed significant price differentiation in unsecured money markets. As described by McAndrews (2009), beforehand reasonably integrated USD money markets showed economically significant price differences along various lines of segmentation. To address stress in the money market, central banks - in particular the Federal Reserve (Fed) - broadened beforehand restricted access to directly provide central bank money to previously non-eligible institutions. While existing literature provides first insights on the effects of various new facilities aimed to broaden access to central bank money, the discussion may profit from addressing the issue from another perspective: given a central bank has initially granted open access to its monetary policy operations, how has price segmentation developed in the unsecured money market under normal and under stressed market conditions? By comparing central banks' access policies and the relative performance of the respective currency's money market, we may gain further insights on the optimal design of the operational framework for the implementation of monetary policy.

We evaluate the degree of price differentiation on the Swiss franc unsecured money market from 2005 to 2011, thus, before and during the financial crisis starting 2007. This market is of particular interest, as the Swiss National Bank (SNB) - in contrast to most other central banks - has followed a very open access policy since 1999. The SNB grants access to its reserve accounts, the payment system as well as to its monetary policy operations to a broad range of domestically chartered intermediaries. In addition, foreign banks and securities broker-dealers that are not chartered in Switzerland are also eligible to participate in the SNB's open market operations and its standing facilities and eventually also in the interbank repo market.

We study price differentiation as a deviation of actual interest rates from the respective Libor (London interbank offered rate) and consider two dimensions of independent differentiation. First, we consider segmentation according to whether or not market participants choose to have direct access to central bank monetary policy operations. Second, we consider cross-border segmentation. Market participants are either domestic (domestic and locally based branches of foreign intermediaries) or foreign intermediaries (that are not chartered in Switzerland).

Regression results show that the Swiss franc unsecured money market is well integrated both during normal and crisis times. Even though an economically significant access premium exists, we find that the SNB's open access policy limits price differentiation and, hence, market segmentation between intermediaries that actually chose to access monetary policy operations as well as the interbank repo market and those that do not. This is inferred from the fact that segmentation has not worsened during the 
financial crisis but rather vanished with the move towards unconventional monetary policy. The fact that the number of participants to the SNB's monetary policy operations and the interbank repo market has increased by $50 \%$ since the start of the financial crisis clearly underpins that an open access policy is valuable. Furthermore, we find that cross-border segmentation is persistent throughout the sample period. Yet, we argue that by granting access to foreign intermediaries that are not chartered in Switzerland, the SNB's open access policy also limits the degree of cross-border segmentation. Again, this holds true both during normal and crisis times.

The paper is structured as follows. Section 2 discusses generic access policies and the one adapted by the SNB. In section 3 we provide a short overview of the literature and summarise findings as so-called implications. Subsequently, we discuss the SNB's responses to the financial crisis. Section 5 provides a short description of the data set used and the econometric methodology applied. The last two sections discuss the results and provide concluding remarks.

\section{Access}

\subsection{Access policy}

A central bank aims to keep the market interest rate at the targeted level offering access to open market operations and standing facilities to a defined set of intermediaries. The provision or absorption of reserves via monetary policy operations is mainly done by means of short-term repo transactions. While there is a huge body of literature dealing with the variety of monetary policy implementation in terms of instruments, we analyse the particular aspect of a central bank's access policy to its monetary policy operations.

A central bank's access policy can be categorised broadly into three types:

(i) Only primary dealers which represent a selection of domestic banks $^{1}$ are eligible (e.g. Fed, Bank of Canada (BoC));

(ii) All domestic banks including subsidiaries of foreign banks which are subject to minimum reserve requirements are eligible (e.g. European Central Bank (ECB), Bank of Japan $(\mathrm{BoJ}))$;

\footnotetext{
${ }^{1}$ Throughout the paper we use the term domestic banks for domestically chartered domestic and foreign banks. In some jurisdiction such as Switzerland, this may also include securities brokers/dealers, insurance companies and asset manager of collective investment schemes. However, in most jurisdictions restricted access is granted only to institutions that are subject to minimum reserve requirements, i.e. banks.
} 
(iii) In addition to domestic and domestically chartered foreign banks, foreign banks that are not chartered domestically are also eligible (e.g. SNB).

Historically, the range of eligible counterparties for monetary policy operations has differed across central banks (see Chailloux et al. (2008) for a more detailed comparison). The Fed has granted access to a selective range of banks. The number of primary dealers peaked at 46 in 1988 and declined to 21 in 2007. As of August 2011, 20 institutions were primary dealers. $^{2}$ In contrast, since 1999 , the SNB has granted access to all domestically chartered banks and securities brokers and dealers (hereinafter domestic banks). ${ }^{3}$ In addition, the SNB also grants access to banks and securities broker-dealers that are not chartered in Switzerland (hereinafter foreign banks). Thus, to obtain Swiss franc liquidity, a foreign bank does not have to establish a branch in Switzerland. ${ }^{4}$

Before March 2009, central banks in major currencies operated in a structural liquidity deficit, i.e. the banking system was a net borrower of liquidity from the central bank. ${ }^{5}$ After reaching the zero lower bound for interest rates in late 2008, various central banks aimed to further loosen monetary policy by creating excess reserves (quantitative easing). By the outright purchase of securities or foreign currencies, for example, central banks moved away from a structural liquidity deficit to a surplus. In doing so, central banks indirectly widened access to their monetary policy operations through the creation of permanent liquidity that was directly distributed to banks in need for liquidity, be it eligible or non-eligible banks.

The transition from a liquidity deficit to a surplus implies that the central bank may have to absorb excess liquidity from the banking system to keep the market interest rate at the targeted level. The central bank's access policy may influence both the effectiveness of its liquidity providing and absorbing operations. For instance, the Fed announced in March 2010 that it widens the range of eligible counterparties for its liquidity absorbing operations to include more intermediaries. ${ }^{6}$ The SNB, in turn, did not have

\footnotetext{
${ }^{2}$ See www.ny.frb.org/markets/primarydealers.html.

${ }^{3}$ Since 2010, the SNB has further opened access to domestically chartered insurance companies and asset managers of collective investment schemes. See SNB (2010b).

${ }^{4}$ The SNB's open access policy is reflected in its collateral framework. It accepts collateral denominated in Swiss franc as well as in EUR, USD, GBP, DKK, NOK and SEK. See section 2.2. In contrast, the Fed and the ECB have solely accepted collateral denominated in their own currency before the crisis. See Cheun at al. (2009) for a discussion of major central banks' collateral policy and the respective adjustments undertaken during the crisis.

${ }^{5} \mathrm{~A}$ structural liquidity position is defined as the net claims or liabilities of the banking system towards the central bank. If the banking system has net liabilities (claims) towards the central bank, it is in a structural liquidity deficit (surplus).

${ }^{6}$ See Fed's press release under www.newyorkfed.org/markets/rrp anouncements.html.
} 
to alter the range of counterparties to include intermediaries that are long in Swiss franc.

\subsection{SNB's access and collateral policy}

In 1999, the SNB has opened access to its monetary policy operations and standing facilities to foreign banks. The original intention of allowing foreign banks to access the SNB's monetary policy operations on a remote basis was to reduce the dependence on the few large Swiss financial institutions and to improve the general liquidity distribution. This aims at facilitating the steering of a longer-term money market rate, namely the 3-month Libor, see Auer and Kraenzlin (2011).

For that purpose, the SNB extended access to reserve accounts from domestic to foreign banks. The same was done for the Swiss payment system (SIC). This has eliminated the requirement to be fully present as a bank in Switzerland in order to be able to settle in central bank money. The SNB conducts its monetary policy operations on Eurex Repo, the Swiss franc repo platform. On the same system the huge majority of interbank repo transactions in Swiss francs are concluded. Access to SNB's reserve accounts and SIC are a requirement to participate in the Swiss franc repo system. All transactions conducted on the platform are settled in SIC and the Swiss CSD (SIX SIS Ltd), which also acts as the Tri-party agent for the repo system. As a rule of thumb, banks that have access to the Swiss repo system are also eligible to participate in the SNB's open market operations and have access to the SNB's standing facilities.

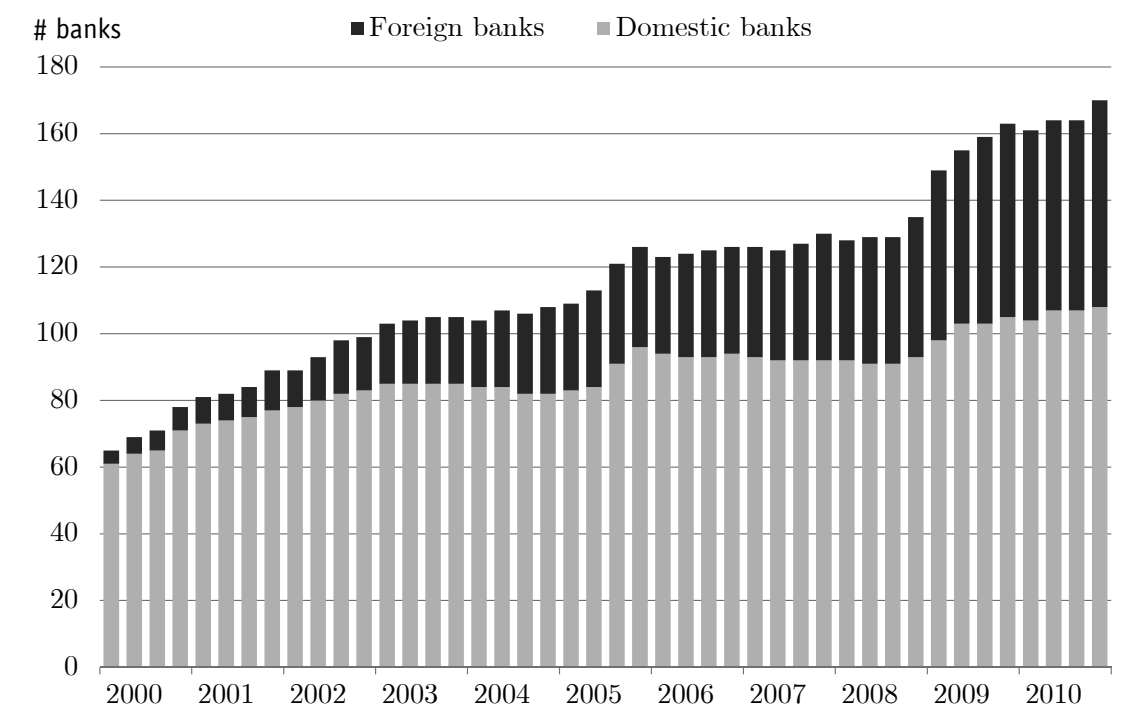

Figure 1: Number of banks with access to Swiss franc repo market 
Figure 1 plots the number of banks in the Swiss franc repo market in grey and black, the number of domestic banks and foreign banks respectively. Back in 1999, when the repo market went operational, it counted 37 banks of which four were not chartered in Switzerland. Since then, the number of banks increased steadily to 170 banks in December 2010, of which 62 participate on a remote basis. Currently, foreign banks are mainly domiciled in Austria (24), Germany (16) and in the UK (6). Since the outbreak of the money market turmoil in August 2007, the number of new participants increased substantially by around 60 participants of which 24 are domestic and 36 are foreign banks. ${ }^{7}$

The SNB's open access policy is also reflected in its collateral framework. The SNB does not only accept collateral denominated in Swiss franc but in diverse foreign currencies. This collateral policy originates from the fact that the Swiss franc capital market is rather small and, as a consequence, the potential range of eligible collateral is too limited to serve as collateral for monetary policy operations. Furthermore, as foreign banks usually do not possess collateral denominated in Swiss francs, the eligibility of collateral denominated in foreign currencies is expected to substantially reduce barriers to enter the Swiss money market for foreign banks.

\section{Literature and implications}

\subsection{Literature}

A central bank's access policy has important implications for the unsecured money market. Depending on the range of eligible counterparties for monetary policy operations and the secured interbank market, the diffusion and allocation of liquidity can alter. Markets with restricted eligibility generate greater interdependencies between financial intermediaries to achieve an efficient allocation of central bank money. This may lead to substantial differences in prices paid by certain categories of market participants.

For instance, McAndrews (2009) provides evidence that interest rates paid in the unsecured money market can deviate substantially from the central banks' targeted rates and differ significantly among different market segments that are defined along the lines of proximity to the central bank. While he relies on market segments that are not clearly distinguished in terms of access and origin, we are able to focus on these dimensions precisely. We measure price differences between the Libor and interests paid by certain segments of the market that we define along the dimensions of access versus no access and domestic versus foreign banks.

\footnotetext{
${ }^{7}$ Note, 16 participants (of which 9 are foreign banks) left the market.
} 
The financial crisis starting 2007 has demonstrated that the unsecured money market may temporarily dry up due to asymmetric information on counterparty risk and liquidity hoarding motives (see Afonso et al. (2011)). By granting access to a wide range of counterparties, involving domestically non-chartered banks, central bank liquidity can flow directly to where it is needed. In particular, broad direct access may prove advantageous in providing liquidity directly to banks that are short and that are avoided in the interbank money market. ${ }^{8}$ Also, Angelini et al. (2011) and Filipovic and Trolle (2011) provide evidence that the allocation of central bank money during the initial phases of the crisis until 2009 was seriously impaired due to liquidity risk on an aggregate level rather than due to credit risk concerns over individual banks. Therefore, in times of market stress, granting access to a wide range of counterparties may become the only way to address reserve imbalances as liquidity can flow directly to where it is needed. This view is supported by Chailloux et al. (2008) who conclude on the 2007 crisis experience by claiming that "in times of distress proximity to the central bank provides more extensive implicit insurance against liquidity events - as well as profit opportunities". In other words, banks with access to central bank monetary policy operations or secured money markets have a comparative advantage over such that do not enjoy this privilege.

Naturally, the question arises whether this is only true during crisis times or whether this assertion also holds during normal times. The presumption by Rochet and Tirole (1996) that market discipline plays an important role in the unsecured money market can be understood as the rationale for granting access to only a selection of domestic banks. Restricted access may prove efficient as market participants - due to their comparative advantage in monitoring peers - can channel funds more effectively and at lower cost than the central bank. ${ }^{9}$ Rochet and Tirole (1996) admit that their view is based on moral hazard rationale while for the money market adverse selection may be a more relevant problem.

Hoerova and Monnet (2012) provide a theory of the joint existence of unsecured and secured money markets next to secured central bank lending that is based on adverse selection. They claim that secured central bank lending may generally improve liquidity allocation in a framework of asym-

\footnotetext{
${ }^{8}$ In addition, broader direct access may reduce the too-big-to-fail problem often associated with primary dealers.

${ }^{9}$ Depending on the instrument as well as the trading and settlement infrastructure used to conduct monetary policy operations, granting access to a wide range of counterparties may imply significant operational costs. In particular, central banks need to monitor their counterparty risk arising from opening access to additional but less creditworthy intermediaries. Granting access to foreign banks may further imply the acceptance of collateral denominated in other currencies because the range of eligible collateral may play an essential role for foreign banks' willingness to participate in the central bank's open market operations. As a consequence, the central bank bears foreign exchange risks.
} 
metric information by eliminating inefficient terminations of projects due to a shortage of central bank liquidity. While their model does not explicitly deal with access but relies on the existence of central bank facilities, essentially, the absence of access is equivalent to the non-existence of these central bank facilities. Therefore, their model provides a rationale that broader access results in welfare gains under both normal and crisis times. In addition, access to secured money markets is not understood to be a perfect substitute to access to central bank monetary policy operations. This assertion is validated by the heavy turmoil that USD repo markets went through during the financial crisis starting 2007 as reported by Gorton and Metrick (2009) and Copeland, Martin and Walker (2010). However, the experience in the Swiss franc repo market was quite different. Kraenzlin and von Scarpatetti (2011 and 2012) find that the Swiss franc repo interbank market proved to be a reliable source of funding for domestic and foreign intermediaries. Although it would be interesting to distinguish between the two forms of access, we are not able to do so because almost all banks that access the interbank repo market also access the SNB.

Next to the segmentation related to access another line of segmentation can develop between domestic and foreign banks as pointed out by Freixas and Holthausen (2004). They provide a model of cross-border interbank market integration under asymmetric information. They find that an equilibrium with integrated markets under noisy cross-country information may not always exist and that an equilibrium characterised by segmentation principally exists or coexists. Furthermore, they show that a repo market reduces interest rate spreads in the unsecured interbank market and improves upon the segmentation equilibrium. However, it may destroy the integrated equilibrium on the unsecured money market. To summarise, they predict cross-border money market segmentation that exists in both normal and crisis times. This segmentation deepens the noisier cross-border information gets - i.e. during crisis times - but is limited by the existence of an interbank repo market.

\subsection{Implications}

We summarise the insights gained in the discussion of the literature with the following five implications that we expect to observe in the data at hand:

\section{Implication 1: A structural liquidity deficit yields a pos- itive access premium}

If the banking system is in a structural liquidity deficit towards the central bank, then banks that access the central bank's monetary policy operations and have available high-quality or central bank-eligible collateral 
pay, on average, a lower interest rate on the unsecured interbank money market. Such banks can rely - apart from the unsecured interbank market - on two alternative sources of refinancing, namely the central bank and the interbank repo market. ${ }^{10}$ Thus, banks with access to central bank money are better insured against liquidity risk in the unsecured interbank market. Consequently, their willingness to pay for liquidity is lower than for banks with no access.

\section{Implication 2: Given a structural liquidity deficit, the size of the access premium can be limited by an open access policy, even in crisis times}

Provided that the banking system is in a structural liquidity deficit, an open access policy to secured money markets and central bank monetary policy operations limits the access premium both in normal and crisis times (as represented by an increasing Libor-OIS spread). As banks - irrespective of their country of domicile - can easily establish direct access to the secured money market or participate in monetary policy operations, they do not exclusively depend on the unsecured money market. Essentially, access to secured refinancing via the central bank or the repo interbank market is a self-selection variable that limits the premium to the cost of establishing access. If the access premium exceeds the cost of establishing access, banks establish access to obtain liquidity on the interbank repo market or from the central bank.

\section{Implication 3: The move from a structural liquidity deficit to a structural liquidity surplus reduces the ac- cess premium}

By means of unconventional measures various central banks provided the banking system with permanent (or relatively long-term) liquidity. The ample supply of permanent liquidity has led to a gradual shift from a structural liquidity deficit to a structural liquidity surplus. This transition implies that the banking system is awash with liquidity and becomes less reliable on the

\footnotetext{
${ }^{10}$ This is particularly true for Switzerland since the infrastructure for the SNB's open market operations is the same as for the large majority of concluded interbank repo transactions in Swiss francs. Therefore, having established access to the Tri-party repo system, a bank can access the interbank repo market and the SNB's monetary policy operations. Furthermore, in contrast to the US Tri-party repo system, the Swiss system runs on bankruptcy remote infrastructure providers that generate no intraday exposures as outlined in Martin, Skeie and von Thadden (2011). Also, the collateral accepted in the interbank market is basically identical to the high quality SNB-eligible collateral. Therefore, central bank operations and interbank repo markets are close substitutes as outlined by Kraenzlin and von Scarpatetti (2011 and 2012).
} 
unsecured interbank market. The central bank indirectly opens access to a wide degree going beyond the number of banks that enjoy direct access to the central bank. This reduces the access premium accordingly as - with an increasing structural liquidity surplus - there is increasing supply of and decreasing demand for liquidity.

\section{Implication 4: The cross-border premium is persistent}

Foreign intermediaries pay, on average, a higher interest rate in the unsecured interbank money market both under a structural liquidity deficit as well as under a structural liquidity surplus. Banks - with a short position in a currency - can refinance themselves (i) via deposits, (ii) via the money and foreign exchange market or (iii) by issuing debt-securities. Banks domiciled domestically finance the vast majority of their lending via deposits. Foreign banks domiciled abroad, in turn, fund themselves rather via the unsecured money market, their local currency's money market (and a corresponding foreign exchange swap into the currency needed) or the capital market. Deposits in the currency needed, on the contrary, are negligible since foreign intermediaries seldom manage large amounts of another currency on their liability side. The inferior importance of deposits implies that foreign banks are more dependent on money and capital markets. The higher dependence on the money market, in turn, leads to a higher willingness to pay for liquidity.

The reasons why the cross-border segmentation premium is not arbitraged out in unsecured money markets are described in Freixas and Holthausen (2004). Essentially, asymmetric information leads to a persistently segmented money market. As Freixas and Holthausen (2004) argue, it is very likely that information on the quality of foreign banks is less precise than home country information. Cash providers do not know whether a bank escapes its home market because it is just short in Swiss franc liquidity or because the bank generated a "bad" signal in its home market and cannot borrow in its local currency (and, in addition, swap the received funds into Swiss francs). Such asymmetries of information are persistent and do not change, because of direct access or when the banking system moves from a structural liquidity deficit to a structural liquidity surplus.

\section{Implication 5: An open access policy limits the cross- border premium}

The willingness of foreign banks to pay a higher premium is limited by an open access policy. Essentially, the same argument as for the access premium applies. However, as foreign banks have a higher relative cost 
to establish money market operations in currencies for which they do not further engage in financial intermediation, the segmentation remains. In a structural liquidity deficit, foreign banks are likely to access central bank money more easily as a central bank aims to accept as many banks with a refinancing need in the respective currency as possible. However, also then, a bank either has to change the composition of the asset side on its balance sheet, which is costly, or it has to carry foreign exchange risk, which may be substantial, particularly during a phase of market turmoil. Therefore, the willingness to pay higher interest rates in the unsecured interbank market remains even in a structural liquidity deficit. The move to a structural liquidity surplus may, thus, not lower the cross-border premium substantially even though the banking system and, hence, also foreign banks are more likely to be awash of liquidity.

\section{The SNB's responses during the crisis}

Next to the access policy, monetary policy implementation by central banks may crucially influence segmentation, particularly so during crisis events. Thus, it is necessary to shortly reflect monetary policy implementation by and the reactions of the SNB to the financial crisis. Before the financial crisis in August 2007 as well as during the first phase of the crisis, the SNB provided liquidity to the banking system via daily repo transactions, normally with a maturity of one week. In total the SNB provided Swiss franc liquidity between 20 and 30 billion (see Figure 2). The higher volume in the first three quarters of 2008 was mainly to compensate an increase in autonomous factors, such as banknotes in circulation or government balances at the SNB.

With the collapse of Lehman Brothers in mid-September 2008, funding costs in the Swiss franc unsecured interbank money market sharply increased in line with other currencies (see the Swiss franc Libor - OIS spread in Figure 2 ). The increase was caused by a combination of the need of foreign banks - which did not have access to interbank repo platform - to continuously roll over maturing interbank loans and the drying up of supply for these funds (see Auer and Kraenzlin (2011) for a more detailed discussion). As a reaction to this, the SNB started to generously provide its counterparties with Swiss franc liquidity. From 28 October 2008 onwards, it started to fully allot all bids submitted in the daily repo auctions. As a result, the outstanding repo volume increased up to Swiss franc 65 billion in 2009.

To more directly allocate liquidity to foreign banks that are seeking Swiss francs, in October 2008, the SNB jointly announced with the ECB and, subsequently, with the Narodowy Bank Polski (NBP) and the Magyar Nemzeti Bank (NMB) to indirectly distribute Swiss franc funds via EURCHF-Swaps with these central banks. Since most banks that have to fund Swiss franc 
liabilities can be served by one of the four central banks mentioned, access to Swiss franc central bank money was further extended. The Swiss franc liquidity provided via Swaps with other central banks quickly reached a level of 65 billion. This reduced the Swiss franc three-month Libor-OIS spread correspondingly (see Figure 2).

In mid March 2009, the SNB announced unconventional measures to combat deflationary risks (see SNB (2009) and SNB (2010a)). The SNB started to conduct longer-term repo transactions, to purchase Swiss franc denominated bonds issued by Swiss private sector borrowers and to intervene in the foreign exchange market. With the foreign exchange interventions the SNB built up a foreign reserve position worth over Swiss franc 200 billion until mid-2010, compared to a pre-2009 level of less than Swiss franc 50 billion. Figure 2 documents the level of foreign exchange interventions. In effect, the SNB provided the banking system with permanent liquidity to an extent that the demand for liquidity in the repo and EURCHF-Swap auctions ceased to exist altogether. As of 12 May 2010, the SNB discontinued its liquidity providing operations.

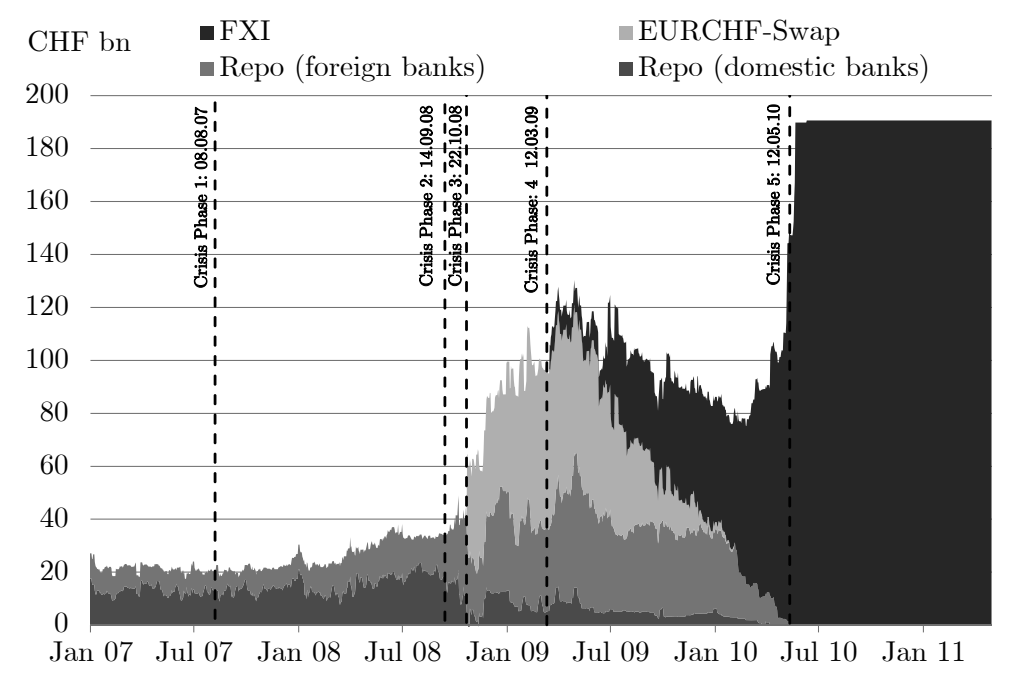

Figure 2: SNB's open market operations

Crisis events and the SNB's measures suggest to distinguish between five crisis phases to evaluate whether the implications suggested are observed in the unsecured money market in Switzerland. The phases are outlined in Figure 2. To compare pre-crisis and crisis segmentation we can rely on data from 2005 to August 2007. Then, the first crisis phase spans the period from the outburst of the crisis to the failure of Lehman. To directly evaluate the effects of the introduction of the EURCHF-Swaps, we distinguish between the phase directly after the collapse of Lehman Brothers and the phase after 


\begin{tabular}{cccccccc} 
& pre-crisis & CP1 & CP2 & CP3 & CP4 & CP5 & Total \\
\hline $1 \mathrm{~W}$ & 3,653 & 1,283 & 24 & 234 & 857 & 755 & 6,806 \\
2W & 932 & 406 & 11 & 47 & 227 & 223 & 1,846 \\
3W & 298 & 166 & 7 & 25 & 99 & 105 & 700 \\
$1 \mathrm{M}$ & 2,692 & 1,167 & 45 & 74 & 404 & 257 & 4,639 \\
$2 \mathrm{M}$ & 1,096 & 417 & 20 & 44 & 207 & 99 & 1,883 \\
3M & 2,371 & 940 & 21 & 68 & 374 & 210 & 3,984 \\
\hline Total & 11,042 & 4,379 & 128 & 492 & 2,168 & 1,649 & 19,858
\end{tabular}

Table 1: Number of trades

the introduction of the EURCHF-Swaps. The fourth crisis phase starts with the SNB's interventions in the foreign exchange market. The fifth crisis phase represents the period after the SNB discontinued its liquidity providing operations.

\section{Data and econometric methodology}

Money market data used is extracted from the Swiss real-time gross settlement (RTGS) system, Swiss Interbank Clearing (SIC). The large-value payment system SIC settles in central bank money. By means of an algorithm similar to the one developed by Furfine (1999) - Guggenheim et al. (2011) extract Swiss franc unsecured interbank money market transactions from the payment system data. The algorithm identifies unsecured interbank transactions between two intermediaries providing information on the interest rate charged, the term as well as the cash amount provided. ${ }^{11}$ The sample used covers transactions from 1 January 2005 to February 2011 with a maturity of one week to three months. We exclude day-to-day transactions as volatility of the interest rate in the unsecured Swiss franc money market is very high and may cause misleading results. ${ }^{12}$

A number of money market players, especially such domiciled outside Switzerland, have not opted to have direct access to SIC. They rely on correspondent banks instead. In particular UBS, Credit Suisse and Zürcher Kantonalbank act as correspondent banks in the Swiss money market. As the data does not allow to identify the final beneficiary (cash taker) and as the interest rate charged on the unsecured money market reflects, among others, the counterparty risk of the cash taker, we exclude transactions related to these three correspondent banks. Furthermore, from this discussion

\footnotetext{
${ }^{11}$ See Guggenheim et al. (2011) for a detailed description of the algorithm and a discussion on its potential drawbacks.

${ }^{12}$ High volatility results from the fact that the SNB conducts its monetary policy by steering the three-month Libor instead of a day-to-day interest rate and does not pay interest rates on reserves.
} 
it becomes evident that we cannot consider money market transactions that are settled on other than SIC accounts.

The data sample counts 19,858 interbank transactions that were conducted on 1,558 business days. Table 1 provides an overview on the number of transactions with respect to the underlying maturity and phases outlined in 2. Overall, 143 banks figured as cash taker in the period of observation. Domestic banks accounted on average for $77 \%$ of the total turnover. Banks with access to the interbank repo market and the SNB - irrespective of their country of domicile - accounted for roughly $75 \%$ of the total turnover (see Figure 4). As one can infer from Figure 3, these numbers remain relatively constant over the sample period. The analysis is based on data from cash takers which were still able to obtain funds on an unsecured basis, i.e. banks that were not avoided in the interbank market due to concerns on their creditworthiness. The number of active participants fell by roughly $40 \%$ after mid 2008 (see Figure 3).

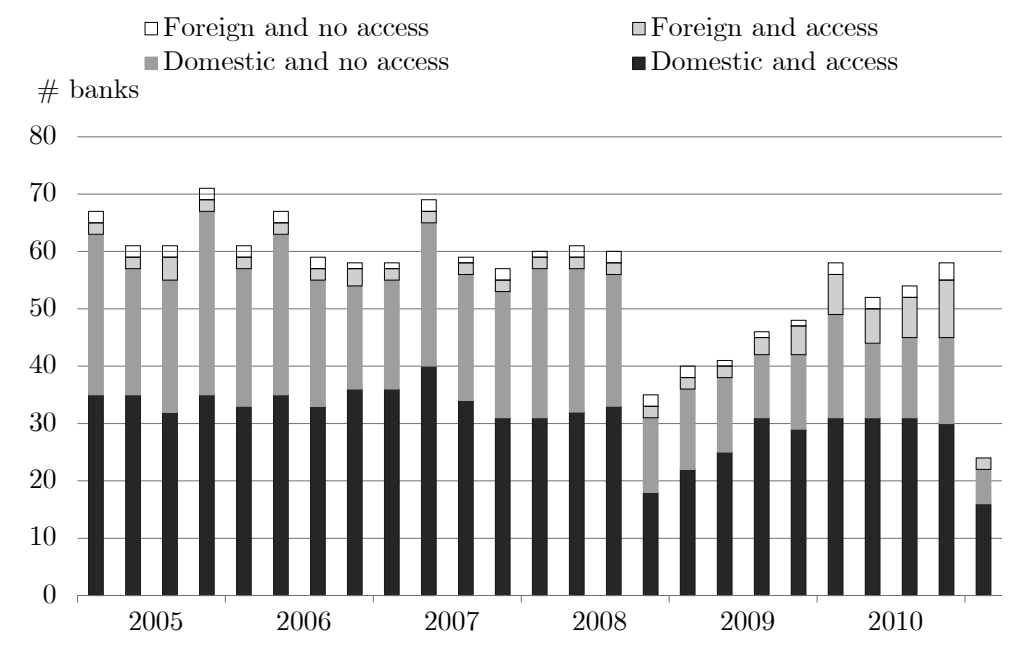

Figure 3: Number of banks active at least once (per quarter)

We identify segmentation in the money market by analysing differences between the interest rate $\left(r_{i, t}^{m}\right)$ paid and the respective Libor rate $\left(L_{i, t}^{m}\right)$. We rely on the interest rate differential $\left(\bar{r}_{i, t}^{m}\right)$ as dependent variable to account for day-to-day differences in the level of interest rates which may, for example, result from interest rate hikes or day-specific tensions that are unrelated to segmentation.

To identify the two possible lines of segmentation, we build two dummy variables. The first one indicates whether the cash taker has access to the SNB and, consequently, to the interbank repo market $\left(d_{t, c b}\right)$. The second one indicates whether the cash taker is a foreign bank $\left(d_{t, f o r}\right)$. To directly 
evaluate the effects of the financial market turmoil as well as the measures applied by the SNB, we define five additional dummy variables $d_{c r i s, j}$ that correspond to the different phases of the financial crisis as explained in section 4 and reported in Figure 2. In doing so, we define six different phases in total, namely the pre-crisis phase and five different crisis phases. Explanatory variables are then derived by multiplying the latter five dummies with former segmentation dummies $d_{t, c b}$ and $d_{t, f o r}$.

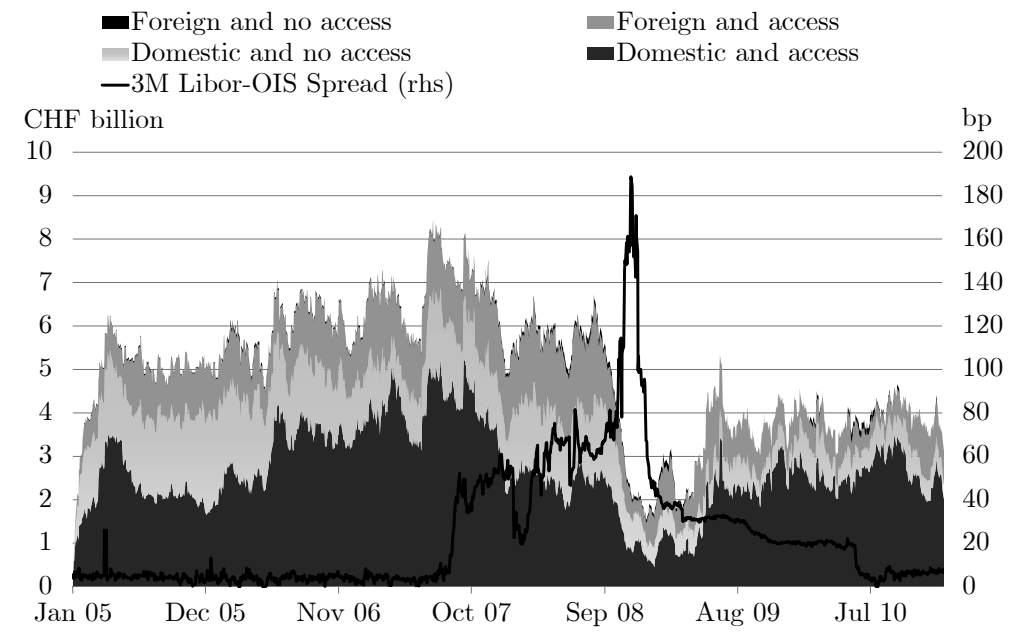

Figure 4: Turnover with respect to bank category

For most banks in the sample neither credit default swap data nor commonly consistent bond spreads are available. However, as highlighted in the literature, the money market was prone to both credit and liquidity risk. Thus, to take account for individual credit risk and liquidity risk premia paid, we construct a proxy for counterparty risk particularly related to the unsecured money market. The Libor-OIS spread is often used as a measure for counterparty and liquidity risk related to stress in the money market. We use the Libor-OIS spread of the respective maturity $\left(r p_{t}^{m}\right)$ and multiply the respective Libor-OIS spread by each cash taker's specific dummy variable $\left(d_{i}\right)$ to account for the individual risk premium $\left(r p_{i, t}^{m}\right)$. In so doing, we presume that individual risk premia are highly correlated with the stress identified in the whole market and depend on the maturity of the transaction.

To further evaluate whether the accentuation of the financial crisis changed the way credit risk is priced, we multiply the individual specific risk premia with additional crisis dummy variables $d_{c r i s, k}$. In Figure 2 five crisis phases are plotted. However, for the purpose at hand, we differentiate between three and not five crisis phases. Namely, we neither distinguish between the 
period shortly after the collapse of Lehman Brothers (crisis phase 2) and the introduction of the EURCHF-Swaps (crisis phase 3) nor between the phase after the foreign exchange interventions (crisis phase 4) and the time when the SNB suspended its liquidity providing operations (crisis phase 5). This is broadly in line with the development of the Libor-OIS spread (see Figure 2).

Finally, to account for unobserved individual specific effects on the cash taker side, which cannot be explained by the explanatory variables, we add a dummy variable $\left(d_{i}\right)$ for $N-1$ cash takers as additional explanatory variable to the regression. Cross-sectional heterogeneity could for example arise due to different liquidity endowments related to a bank's business strategy. If so, cash providers could try to take advantage of such a setting and ask for higher interest rates. In contrast, if a bank is state-owned, it may profit from persistently lower interest rates. Such influences are of a structural nature over the whole sample which is why an individual dummy is appropriate to capture these effects.

$$
\begin{gathered}
\bar{r}_{i, t}^{m}=\sum_{i=1}^{N-1} \alpha_{i} d_{i}+\sum_{j=0}^{5} \beta_{j} d_{c r i s, j} d_{t, c b}+\sum_{j=0}^{5} \gamma_{j} d_{c r i s, j} d_{t, f o r}+ \\
\sum_{k=0}^{3} \sum_{i=1}^{N} \delta_{i, k} r p_{t}^{m} d_{r p, c r i s, k} d_{i}+\varepsilon_{i, t}
\end{gathered}
$$

Instead of using the fixed effects (FE) or random effects (RE) approach, we run a so-called least squares dummy variable (LSDV) regression. ${ }^{13}$ The LSDV regression is a pooled ordinary least squares (OLS) regression and yields identical coefficients for the independent variables as the $\mathrm{FE}$ regression would. We run a LSDV regression instead of the FE regression because of three reasons: First, transactions on the unsecured interbank money market are not concluded every day due to holidays and weekends. This results in an unequally spaced dataset. Second, the dataset is unbalanced because banks do not participate daily in money markets. Finally, some banks conduct several trades per trading day (up to 15 trades), resulting in more than just one observation per day and bank (implying a high frequency pattern).

For all sample periods the following static regression is estimated where i denotes the cross-sectional dimension (N-1 banks), m denotes the maturity of the transaction considered (one week to three months), $\mathrm{j}$ and $\mathrm{k}$ denote the number of crisis phases and $t$ denotes the time-series ( $\mathrm{T}$ days) dimension. We define domestic banks without access to the SNB and the interbank repo market as the reference group and $d_{c r i s, j=0}$ as well as $d_{r p, c r i s, k=0}$ equal one throughout the sample.

\footnotetext{
${ }^{13}$ See Baltagi (2005).
} 


\section{Regression results}

Regression results are displayed in Table $6 .{ }^{14}$ Results provide strong evidence that the value of access to monetary policy operations and the interbank repo market is at an economically relevant level, being estimated at $6.3 \mathrm{bp}$ for the pre-crisis phase.

Obviously, for some market participants potential savings do not justify the investment to establish access, at least under normal market conditions. Therefore, arbitrage works to a degree that makes participants without access are indifferent. In particular, this assertion is backed by the fact that the change in the access premium is not significantly different from zero during the first two phases of the financial crisis, in which the banking system was still in a structural liquidity deficit. This evidence strongly supports the first implication discussed initially.

Despite an access premia of $6.3 \mathrm{bp}$, we judge the Swiss money market to be highly integrated. This is confirmed, for instance, by McAndrews (2009), who estimates premia along related segmentations in the USD market to be around 10 to $30 \mathrm{bp}$ during normal times. In contrast to the Swiss case, access to USD central bank money is not a self-selection variable as only 20 primary dealers are allowed to access the Fed's open market operations. Thus, arbitrage between different segments of the USD money market is more difficult. This strongly supports the second implication that open access limits the degree of segmentation. Further evidence for the value of access is provided by the fact that more than 60 institutions have chosen to access the SNB and the Swiss franc repo market since the outbreak of the crisis.

Starting October 2008 the access premium started to decrease with each additional monetary policy measure taken by the SNB to basically vanish in the last period considered. In other words, after the introduction of EURCHF-Swaps in concert with foreign central banks and the subsequent widening of the range of counterparties in October 2008, the access premium declined by roughly $1.8 \mathrm{bp}$. With the provision of permanent liquidity via foreign exchange interventions in the amount of 190 billion Swiss franc, the majority of the banks became awash with Swiss franc liquidity and, as a consequence, access to the interbank repo market and the SNB became less valuable (1.7bp). As of 12 May 2010, the SNB discontinued its liquidity providing operations. Since then, the SNB has no longer represented a refinancing source and, hence, the access premium has become insignificant.

\footnotetext{
${ }^{14}$ The coefficients on the individual specific dummy variables and risk premia - in total 457 coefficients - are not displayed in the table but can be received - on an anonymous basis - upon request.
} 


\begin{tabular}{lcccc} 
& Coefficient & Std. error & Total impact & F-test with $d_{c b} / d_{f o r}$ \\
\hline$d_{c b}$ & $-6.27^{* * *}$ & -0.005 & $-6.27^{* * *}$ & \\
$d_{c b, P 1}$ & $-0.43^{*}$ & -0.002 & $-6.70^{* * *}$ & $132.6(0.00)$ \\
$d_{c b, P 2}$ & -0.32 & -0.016 & $-6.59^{* * *}$ & $16.33(0.00)$ \\
$d_{c b, P 3}$ & $1.77^{* *}$ & -0.007 & $-4.50^{* * *}$ & $25.96(0.00)$ \\
$d_{c b, P 4}$ & $4.53^{* * *}$ & -0.003 & $-1.74^{* * *}$ & $8.16(0.00)$ \\
$d_{c b, P 5}$ & $5.37^{* * *}$ & -0.002 & -0.90 & $2.53(0.11)$ \\
$d_{f o r}$ & $4.79^{* * *}$ & -0.008 & $4.79^{* * *}$ & \\
$d_{f o r, P 1}$ & $-1.11^{* * *}$ & -0.004 & $3.68^{* * *}$ & $20.01(0.00)$ \\
$d_{f o r, P 2}$ & 1.52 & -0.021 & $6.31^{* * *}$ & $7.98(0.00)$ \\
$d_{f o r, P 3}$ & -0.07 & -0.012 & $4.72^{* * *}$ & $12.17(0.00)$ \\
$d_{f o r, P 4}$ & $-1.84^{* * *}$ & -0.006 & $2.95^{* * *}$ & $11.34(0.00)$ \\
$d_{\text {for,P5 }}-1.27^{* *}$ & -0.006 & $3.52^{* * *}$ & $38.81(0.00)$ \\
\hline No. Obs. & \multicolumn{5}{c}{19,858} & \\
R-squared & 0.5221 & \\
Adj. R-squared & 0.5105 & \\
\hline ***: significance on the $1 \%$ level; ${ }^{* *}: 5 \%$ level; $*: 10 \%$ level;
\end{tabular}

Table 2: Regression results (in bp)

Thus, the vanishing access premium found for the three last crisis periods supports the third implication. A central bank's unconventional monetary policy measures in response to the financial crisis reduce the access premium. Essentially, unconventional monetary policy measures open access to central bank money to any counterparty seeking liquidity. In the case of the SNB, this is particularly true so for the fourth crisis phase (FX interventions). The access premium decreased in line with the SNB's monetary policy measures that led to a structural liquidity surplus.

Cross-border segmentation is present in the unsecured Swiss money market, resulting in a significant cross-border premium between 3 to $6.3 \mathrm{bp}$ for foreign banks. However, even though cross-border segmentation is persistent and on an economically relevant level, segmentation is rather low compared to the evidence found by McAndrews (2009) for similar segmentations in the USD money market. In particular, the segmentation in the Swiss franc money market has not increased significantly during the crisis. The cross-border segmentation looks persistent as it does not change fundamentally over time and it does not depend on the fact whether a foreign bank has access or not. This is in sharp contrast to the price segmentations McAndrews (2009) finds for different segments of the USD market with peaks at a level above 150bp. These findings are consistent with the last two implications proposed, namely that cross-border segmentation is persistent but limited by an open access policy. 


\section{Conclusions}

In the paper we evaluate two possible lines of market segmentation in the Swiss franc unsecured money market, namely access to the repo market and SNB's monetary policy operations as well as country of domicile (domestic vs. foreign). We find that both lines of segmentation are economically relevant, but smaller than comparable estimates for the USD money market. Our findings on the Swiss franc money market suggest that an open access policy to interbank repo markets and monetary policy operations can limit money market segmentation during normal as well as times of financial turmoil. In effect, an open access policy fosters efficiency and stability of the unsecured money market and, as a consequence, the efficacy of monetary policy transmission. The evidence found provides a strong case to widen the focus of monetary policy implementation and financial stability to include the optimal access policy to interbank repo markets and monetary policy operations.

Broadly speaking, there are three different levels of access policy central banks can adhere to: first, a restrictive policy granting access to a selection of domestic banks (primary dealers), second, a domestic oriented policy with solely domestic chartered banks, and, finally, an open access policy that also admits access to foreign banks that are not chartered domestically. The SNB follows the latter open access approach. The evidence found supports the presumption that an open access policy can contain segmentation in the unsecured money market.

In the Swiss franc unsecured money market, we observe an access premium that is limited by the SNB's open access policy. The unsecured interbank money market does not ask too high a premium from banks without access. If there were too high a mark-up, banks would establish access to the SNB and, as a consequence, to the Swiss franc interbank repo market. The fact that 60 banks have established access to the Swiss franc repo platform since the start of the financial crisis is indicative that the degree of segmentation can be limited with this open access policy.

We identify persistent cross-border segmentation, leading to the conclusion that cross-border segmentation does not depend on the access policy per se. However, above line of argument holds true for foreign banks too. The fact that segmentation has not become worse for foreign banks during the different phases of financial turmoil can be ascribed to the open access policy which puts an upper limit on foreign banks' willingness to pay. In other words, remote access to repo markets and the central bank's monetary policy operations limits the extent of market segmentation. Also, the fact that many foreign banks were among the 60 banks seeking access during the crisis is indicative for an open access policy to limit cross-border segmentation. 
Direct access to central bank money has been a main instrument to ease stress in the money markets during the financial crisis starting 2007. Our results suggest that access to central bank money is beneficial. However, as for we cannot distinguish access to central bank operations and access to the secured money market, we are not able to disentangle the contribution of each form of secured refinancing. Comparable research for other currencies may, thus, be able to shed further light on the optimal access policy. 


\section{References}

Afonso, G., A. Kovner and A. Schoar (2011). Stressed, Not Frozen: The Federal Funds Market in the Financial Crisis. Journal of Finance, 66 (4), 1109-1139.

Angelini, P., A. Nobili and C. Picillo (2011). The Interbank Market after August 2007: What Has Changed, and Why? Journal of Money, Credit and Banking, Vol. 43, No. 5, 923-58.

Auer R. and S. Kraenzlin (2011). International liquidity provision during the financial crisis: A view from Switzerland. Federal Reserve Bank of St. Louis Review, November/December 2011 Vol. 93, No. 6, pp. 409-418.

Baltagi, B. (2005). Econometric Analysis of Panel Data. John Wiley \& Sons, 3rd edition, 2005.

Chailloux, A., S. Gray, U. Kh, S. Shimizu and P. Stella (2008). Central Bank Response to the 2007-08 Financial Market Turbulence: Experiences and Lessons Drawn. IMF Working Paper, WP/08/210.

Cheun, Samuel, Isabel von Kppen-Mertes and Benedict Weller (2009). The Collateral Frameworks of the Eurosystem, the Federal Reserve System and the Bank of England and the Financial Market Turmoil. European Central Bank, Occassional Paper Series 107.

Copeland, Adam, Antoine Martin and Michael Walker (2010). The Tri-Party Repo Market before the 2010 Reforms. Federal Reserve Bank of New York Staff Report 477, November 2010.

Filipovic, D. and A. Trolle (2011). The Term Structure of Interbank Risk. Mimeo, EPFL Lausanne.

Furfine, C. (1999). The microstructure of the Federal Funds Market. Financial Markets, Institutions and Instruments, Volume 8, No. 5, November 1999.

Freixas, X. and C. Holthausen (2004). Interbank market integration under asymmetric information. Review of Financial Studies, 18(2), 459-90.

Gorton, Gary and Andrew Metrick (2012). Securities Banking and the Run on Repo. Journal of Financial Economics, 104, 425-451.

Guggenheim, B., S. Kraenzlin and S. Schumacher (2011). Exploring an uncharted market: Evidence on the unsecured Swiss franc money market. Aussenwirtschaft, Vol. 66, 59-87.

Hoerova, M. and C. Monnet (2012). Endogenous adverse selection, market discipline, and central bank lending. Mimeo. University of Berne. 
Kraenzlin, S. and B. von Scarpatetti (2011). Bargaining Power in the Repo Market. SNB Working Paper 2011-14.

Kraenzlin, S. and B. von Scarpatetti (2012). Liaisons and Scheming: The Network of the Swiss Franc Repo Market. Forthcoming as SNB Working Paper.

Martin, Antoine, David Skeie and Ernst-Ludwig von Thadden (2010). Repo Runs. Federal Reserve Bank of New York Staff Report 444, April 2010.

McAndrews, J. (2009). Segmentation in the U.S. Dollar Money Markets During the Financial Crisis. Mimeo, Federal Reserve Bank of New York.

Rochet, J.-C. and J. Tirole (1996). Interbank Lending and Systemic Risk. Journal of Money, Credit, and Banking 28, 733-762.

Swiss National Bank (2009). 102 Annual Report 2009.

Swiss National Bank (2010a). 103 Annual Report 2010.

Swiss National Bank (2010b). Circular letter to banks: Insurance companies as new participants in the repo system, Equal treatment with regard to withholding tax. 


\section{Swiss National Bank Working Papers published since 2004:}

2004-1 Samuel Reynard: Financial Market Participation and the Apparent Instability of Money Demand

2004-2 Urs W. Birchler and Diana Hancock: What Does the Yield on Subordinated Bank Debt Measure?

2005-1 Hasan Bakhshi, Hashmat Khan and Barbara Rudolf: The Phillips curve under state-dependent pricing

2005-2 Andreas M. Fischer: On the Inadequacy of Newswire Reports for Empirical Research on Foreign Exchange Interventions

2006-1 Andreas M. Fischer: Measuring Income Elasticity for Swiss Money Demand: What do the Cantons say about Financial Innovation?

2006-2 Charlotte Christiansen and Angelo Ranaldo: Realized Bond-Stock Correlation: Macroeconomic Announcement Effects

2006-3 Martin Brown and Christian Zehnder: Credit Reporting, Relationship Banking, and Loan Repayment

2006-4 Hansjörg Lehmann and Michael Manz: The Exposure of Swiss Banks to Macroeconomic Shocks - an Empirical Investigation

2006-5 Katrin Assenmacher-Wesche and Stefan Gerlach: Money Growth, Output Gaps and Inflation at Low and High Frequency: Spectral Estimates for Switzerland

2006-6 Marlene Amstad and Andreas M. Fischer: Time-Varying Pass-Through from Import Prices to Consumer Prices: Evidence from an Event Study with Real-Time Data

2006-7 Samuel Reynard: Money and the Great Disinflation

2006-8 Urs W. Birchler and Matteo Facchinetti: Can bank supervisors rely on market data? A critical assessment from a Swiss perspective

2006-9 Petra Gerlach-Kristen: A Two-Pillar Phillips Curve for Switzerland

2006-10 Kevin J. Fox and Mathias Zurlinden: On Understanding Sources of Growth and Output Gaps for Switzerland

2006-11 Angelo Ranaldo: Intraday Market Dynamics Around Public Information Arrivals

2007-1 Andreas M. Fischer, Gulzina Isakova and Ulan Termechikov: Do FX traders in Bishkek have similar perceptions to their London colleagues? Survey evidence of market practitioners' views 
2007-2 Ibrahim Chowdhury and Andreas Schabert: Federal Reserve Policy viewed through a Money Supply Lens

2007-3 Angelo Ranaldo: Segmentation and Time-of-Day Patterns in Foreign Exchange Markets

2007-4 Jürg M. Blum: Why ‘Basel II’ May Need a Leverage Ratio Restriction

2007-5 Samuel Reynard: Maintaining Low Inflation: Money, Interest Rates, and Policy Stance

2007-6 Rina Rosenblatt-Wisch: Loss Aversion in Aggregate Macroeconomic Time Series

2007-7 Martin Brown, Maria Rueda Maurer, Tamara Pak and Nurlanbek Tynaev: Banking Sector Reform and Interest Rates in Transition Economies: Bank-Level Evidence from Kyrgyzstan

2007-8 Hans-Jürg Büttler: An Orthogonal Polynomial Approach to Estimate the Term Structure of Interest Rates

2007-9 Raphael Auer: The Colonial Origins Of Comparative Development: Comment. A Solution to the Settler Mortality Debate

2007-10 Franziska Bignasca and Enzo Rossi: Applying the Hirose-Kamada filter to Swiss data: Output gap and exchange rate pass-through estimates

2007-11 Angelo Ranaldo and Enzo Rossi: The reaction of asset markets to Swiss National Bank communication

2007-12 Lukas Burkhard and Andreas M. Fischer: Communicating Policy Options at the Zero Bound

2007-13 Katrin Assenmacher-Wesche, Stefan Gerlach, and Toshitaka Sekine: Monetary Factors and Inflation in Japan

2007-14 Jean-Marc Natal and Nicolas Stoffels: Globalization, markups and the natural rate of interest

2007-15 Martin Brown, Tullio Jappelli and Marco Pagano: Information Sharing and Credit: Firm-Level Evidence from Transition Countries

2007-16 Andreas M. Fischer, Matthias Lutz and Manuel Wälti: Who Prices Locally? Survey Evidence of Swiss Exporters

2007-17 Angelo Ranaldo and Paul Söderlind: Safe Haven Currencies 
2008-1 Martin Brown and Christian Zehnder: The Emergence of Information Sharing in Credit Markets

2008-2 Yvan Lengwiler and Carlos Lenz: Intelligible Factors for the Yield Curve

2008-3 Katrin Assenmacher-Wesche and M. Hashem Pesaran: Forecasting the Swiss Economy Using VECX* Models: An Exercise in Forecast Combination Across Models and Observation Windows

2008-4 Maria Clara Rueda Maurer: Foreign bank entry, institutional development and credit access: firm-level evidence from 22 transition countries

2008-5 Marlene Amstad and Andreas M. Fischer: Are Weekly Inflation Forecasts Informative?

2008-6 Raphael Auer and Thomas Chaney: Cost Pass Through in a Competitive Model of Pricing-to-Market

2008-7 Martin Brown, Armin Falk and Ernst Fehr: Competition and Relational Contracts: The Role of Unemployment as a Disciplinary Device

2008-8 Raphael Auer: The Colonial and Geographic Origins of Comparative Development

2008-9 Andreas M. Fischer and Angelo Ranaldo: Does FOMC News Increase Global FX Trading?

2008-10 Charlotte Christiansen and Angelo Ranaldo: Extreme Coexceedances in New EU Member States' Stock Markets

2008-11 Barbara Rudolf and Mathias Zurlinden: Measuring capital stocks and capital services in Switzerland

2008-12 Philip Sauré: How to Use Industrial Policy to Sustain Trade Agreements

2008-13 Thomas Bolli and Mathias Zurlinden: Measuring growth of labour quality and the quality-adjusted unemployment rate in Switzerland

2008-14 Samuel Reynard: What Drives the Swiss Franc?

2008-15 Daniel Kaufmann: Price-Setting Behaviour in Switzerland - Evidence from CPI Micro Data

2008-16 Katrin Assenmacher-Wesche and Stefan Gerlach: Financial Structure and the Impact of Monetary Policy on Asset Prices

2008-17 Ernst Fehr, Martin Brown and Christian Zehnder: On Reputation: A Microfoundation of Contract Enforcement and Price Rigidity 
2008-18 Raphael Auer and Andreas M. Fischer: The Effect of Low-Wage Import Competition on U.S. Inflationary Pressure

2008-19 Christian Beer, Steven Ongena and Marcel Peter: Borrowing in Foreign Currency: Austrian Households as Carry Traders

2009-1 Thomas Bolli and Mathias Zurlinden: Measurement of labor quality growth caused by unobservable characteristics

2009-2 Martin Brown, Steven Ongena and Pinar Yeșin: Foreign Currency Borrowing by Small Firms

2009-3 Matteo Bonato, Massimiliano Caporin and Angelo Ranaldo: Forecasting realized (co)variances with a block structure Wishart autoregressive model

2009-4 Paul Söderlind: Inflation Risk Premia and Survey Evidence on Macroeconomic Uncertainty

2009-5 Christian Hott: Explaining House Price Fluctuations

2009-6 Sarah M. Lein and Eva Köberl: Capacity Utilisation, Constraints and Price Adjustments under the Microscope

2009-7 Philipp Haene and Andy Sturm: Optimal Central Counterparty Risk Management

2009-8 Christian Hott: Banks and Real Estate Prices

2009-9 Terhi Jokipii and Alistair Milne: Bank Capital Buffer and Risk Adjustment Decisions

2009-10 Philip Sauré: Bounded Love of Variety and Patterns of Trade

2009-11 Nicole Allenspach: Banking and Transparency: Is More Information Always Better?

2009-12 Philip Sauré and Hosny Zoabi: Effects of Trade on Female Labor Force Participation

2009-13 Barbara Rudolf and Mathias Zurlinden: Productivity and economic growth in Switzerland 1991-2005

2009-14 Sébastien Kraenzlin and Martin Schlegel: Bidding Behavior in the SNB's Repo Auctions

2009-15 Martin Schlegel and Sébastien Kraenzlin: Demand for Reserves and the Central Bank's Management of Interest Rates

2009-16 Carlos Lenz and Marcel Savioz: Monetary determinants of the Swiss franc 
2010-1 Charlotte Christiansen, Angelo Ranaldo and Paul Söderlind: The Time-Varying Systematic Risk of Carry Trade Strategies

2010-2 Daniel Kaufmann: The Timing of Price Changes and the Role of Heterogeneity

2010-3 Loriano Mancini, Angelo Ranaldo and Jan Wrampelmeyer: Liquidity in the Foreign Exchange Market: Measurement, Commonality, and Risk Premiums

2010-4 Samuel Reynard and Andreas Schabert: Modeling Monetary Policy

2010-5 Pierre Monnin and Terhi Jokipii: The Impact of Banking Sector Stability on the Real Economy

2010-6 Sébastien Kraenzlin and Thomas Nellen: Daytime is money

2010-7 Philip Sauré: Overreporting Oil Reserves

2010-8 Elizabeth Steiner: Estimating a stock-flow model for the Swiss housing market

2010-9 Martin Brown, Steven Ongena, Alexander Popov, and Pinar Yeșin: Who Needs Credit and Who Gets Credit in Eastern Europe?

2010-10 Jean-Pierre Danthine and André Kurmann: The Business Cycle Implications of Reciprocity in Labor Relations

2010-11 Thomas Nitschka: Momentum in stock market returns: Implications for risk premia on foreign currencies

2010-12 Petra Gerlach-Kristen and Barbara Rudolf: Macroeconomic and interest rate volatility under alternative monetary operating procedures

2010-13 Raphael Auer: Consumer Heterogeneity and the Impact of Trade Liberalization: How Representative is the Representative Agent Framework?

2010-14 Tommaso Mancini Griffoli and Angelo Ranaldo: Limits to arbitrage during the crisis: funding liquidity constraints and covered interest parity

2010-15 Jean-Marc Natal: Monetary Policy Response to Oil Price Shocks

2010-16 Kathrin Degen and Andreas M. Fischer: Immigration and Swiss House Prices

2010-17 Andreas M. Fischer: Immigration and large banknotes

2010-18 Raphael Auer: Are Imports from Rich Nations Deskilling Emerging Economies? Human Capital and the Dynamic Effects of Trade 
2010-19 Jean-Pierre Danthine and John B. Donaldson: Executive Compensation: A General Equilibrium Perspective

2011-1 Thorsten Beck and Martin Brown: Which Households Use Banks? Evidence from the Transition Economies

2011-2 Martin Brown, Karolin Kirschenmann and Steven Ongena: Foreign Currency Loans Demand or Supply Driven?

2011-3 Victoria Galsband and Thomas Nitschka: Foreign currency returns and systematic risks

2011-4 Francis Breedon and Angelo Ranaldo: Intraday patterns in FX returns and order flow

2011-5 Basil Guggenheim, Sébastien Kraenzlin and Silvio Schumacher: Exploring an uncharted market: Evidence on the unsecured Swiss franc money market

2011-6 Pamela Hall: Is there any evidence of a Greenspan put?

2011-7 Daniel Kaufmann and Sarah Lein: Sectoral Inflation Dynamics, Idiosyncratic Shocks and Monetary Policy

2011-8 Iva Cecchin: Mortgage Rate Pass-Through in Switzerland

2011-9 Raphael A. Auer, Kathrin Degen and Andreas M. Fischer: Low-Wage Import Competition, Inflationary Pressure, and Industry Dynamics in Europe

2011-10 Raphael A. Auer and Philip Sauré: Spatial Competition in Quality, Demand-Induced Innovation, and Schumpeterian Growth

2011-11 Massimiliano Caporin, Angelo Ranaldo and Paolo Santucci de Magistris: On the Predictability of Stock Prices: a Case for High and Low Prices

2011-12 Jürg Mägerle and Thomas Nellen: Interoperability between central counterparties

2011-13 Sylvia Kaufmann: K-state switching models with endogenous transition distributions

2011-14 Sébastien Kraenzlin and Benedikt von Scarpatetti: Bargaining Power in the Repo Market

2012-01 Raphael A. Auer: Exchange Rate Pass-Through, Domestic Competition, and Inflation: Evidence from the 2005/08 Revaluation of the Renminbi

2012-02 Signe Krogstrup, Samuel Reynard and Barbara Sutter: Liquidity Effects of Quantitative Easing on Long-Term Interest Rates 
2012-03 Matteo Bonato, Massimiliano Caporin and Angelo Ranaldo: Risk spillovers in international equity portfolios

2012-04 Thomas Nitschka: Banking sectors' international interconnectedness: Implications for consumption risk sharing in Europe

2012-05 Martin Brown, Steven Ongena and Pinar Yeşin: Information Asymmetry and Foreign Currency Borrowing by Small Firms

2012-06 Philip Sauré and Hosny Zoabi: Retirement Age across Countries: The Role of Occupations

2012-07 Christian Hott and Terhi Jokipii: Housing Bubbles and Interest Rates

2012-08 Romain Baeriswyl and Camille Cornand: Reducing overreaction to central bank's disclosures: theory and experiment

2012-09 Bo E. Honoré, Daniel Kaufmann and Sarah Lein: Asymmetries in Price-Setting Behavior: New Microeconometric Evidence from Switzerland

2012-10 Thomas Nitschka: Global and country-specific business cycle risk in time-varying excess returns on asset markets

2012-11 Raphael A. Auer, Thomas Chaney and Philip Sauré: Quality Pricing-to-Market

2012-12 Sébastien Kraenzlin and Thomas Nellen: Access policy and money market segmentation 
Swiss National Bank Working Papers are also available at www.snb.ch, section Publications/Research Subscriptions or individual issues can be ordered at Swiss National Bank, Fraumünsterstrasse 8, CH-8022 Zurich, fax+41 4463181 14, E-mail library@snb.ch 